\title{
Extended spectrum $\beta$-lactamase (ESBL)-producing Escherichia coli inactivation by UVA-LED irradiation system in a Japanese hospital
}

\section{Maria Ulfa}

Department of Preventive Environment and Nutrition, Institute of Biomedical Sciences, Tokushima University Graduate School

\section{Momoyo Azuma}

Department of Infection Control and Prevention, Tokushima University Hospital

\section{Masami Sato}

Division of Medical Technology, Tokushima University Hospital

\section{Takaaki Shimohata ( $\nabla$ shimohata@tokushima-u.ac.jp)}

Institute of Biomedical Sciences Tokushima University Graduate School

\section{Shiho Fukushima}

Department of Preventive Environment and Nutrition, Institute of Biomedical Sciences, Tokushima University Graduate School

\section{Junko Kido}

Department of Preventive Environment and Nutrition, Institute of Biomedical Sciences, Tokushima University Graduate School

\section{Mariko Nakamoto}

Department of Publich Health and Applied Nutrition, Institute of Biomedical Sciences, Tokushima University Graduate School

\section{Takashi Uebanso}

Department of Preventive Environment and Nutrition, Institute of Biomedical Sciences, Tokushima University Graduate School

\section{Kazuaki Mawatari}

Department of Preventive Environment and Nutrition, Institute of Biomedical Sciences, Tokushima University Graduate School

\section{Takahiro Emoto}

Department of Electrical Engineering, Institute of Socio Techno Sciences, Tokushima University Graduate School

\section{Masatake Akutagawa}

Department of Elcetrical and Electronic Engineering, Institute of Socio Techno Sciences, Tokushima University Graduate School

\section{Yohsuke Kinouchi}


Department of Elcetrical and Electronic Engineering, Institute of Socio Techno Sciences, Tokushima University Graduate School

\section{Akira Takahashi}

Department of Prevenetive Environment and Nutrition, Institute of Biomedical Sciences, Tokushima University Graduate School

\section{Research}

Keywords: extended spectrum b-lactamase (ESBL, ESBL- E. coli, E. coli, UVA-LED irradiation

Posted Date: January 19th, 2020

DOI: https://doi.org/10.21203/rs.2.18734/v2

License: (c) (1) This work is licensed under a Creative Commons Attribution 4.0 International License. Read Full License 
The authors have withdrawn this preprint from Research Square 